\title{
COMPARATIVE ANALYSIS OF TWO HIGH-SPEED SINGLE-PHASE ELECTRICAL MACHINES WITH PERMANENT MAGNETS ON THE STATOR
}

\begin{abstract}
Purpose. Single-phase machines with permanent magnets on the rotor are widely used in a variety of applications of a low rated power. When these machines are applied in high-speed applications, a retaining ring on the rotor core must be often used. However, it makes the assembly more complex and the high-speed machines become more expensive. On the other hand, machines with magnets on the stator still can be a valuable alternative due to their simple and reliable rotor design. In this paper the comparative study of performances of two single-phase electrical machines with magnets on the stator (flux reversal electrical machine and hybrid switched reluctance machine) is presented. The following performances have been compared: efficiency, weight, active materials cost, value of rated current of switches of the frequency converter. Methodology. Calculation of electrical machines performances using solving two-dimension boundary magnetostatics problems. Results. The theoretical comparison of the flux reversal electrical machine and the hybrid switched reluctance machine has been carried out; the comparison on specific torque and efficiency of the two aforementioned machines have been obtained. The flux reversal machine has a significantly higher efficiency and a fewer weight. In addition, it has a lower value of rated current. On the contrary, the cost of active materials of the hybrid switched reluctance one is much less. Originality. The presented results can assist in selecting the best design alternative of electrical machines in the following applications: electrical blowers, household appliances, fans, pumps and compressors of a low rated power etc. Practical value. The comparisons results of the flux reversal electrical machine and the hybrid switched reluctance machine has been obtained for the first time. References 15, tables 2, figures 13.

Key words: high speed machines, hybrid switched reluctance machine, flux reversal electrical machine, permanent magnet machine, single-phase electrical machine, special electrical machine.
\end{abstract}

Мета. Дослідження характеристик двох високошвидкісних однофазних електричних машин з магнітами на статорі (електрична машина зі змінним напрямом потоку $і$ гібридна вентильно-індукторна реактивна машина): порівнюються такі характеристики як ККД, вага, вартість активних матеріалів, номінальний струм елементів перетворювача частоти. Методика. Розрахунок характеристик електричної машини за допомогою рішення двомірних крайових магнітостатичних завдань. Результати. Проведено порівняння двох типів однофазних машин 3 магнітами на статорі; отримано розрахункове порівняння характеристик однофазної електричної машини зі змінним напрямом потоку і однофазної гібридної вентильно-індукторної реактивної машини; отримані результати порівняння маси, розмірів і ККД двох машин. Наукова новизна. Уперше отримані результати порівняння однофазної електричної машини зі змінним напрямом потоку і однофазної гібридної вентильно-індукторної реактивної машини. Практичне значення. Отримані результати можуть допомогти при виборі крацої конструкцї̈ електродвигуна в даних застосуваннях: електричне турбонаддування, побутові прилади, вентилятори, насоси $і$ компресори малої потужнності і т.д. Бібл. 15, табл. 2, рис. 13.

Ключові слова: високошвидкісні машини, гібридна вентильно-індукторна реактивна машина, машина зі змінним напрямом магнітного потоку, машина з постійними магнітами, однофазні електричні машини, спеціальні електричні машини.

Цель. Исследование характеристик двух высокоскоростных однофазных электрических машин с магнитами на статоре (электрическая машина с переменным направлением потока и гибридная вентильно-индукторная реактивная машина): сравниваются такие характеристики как КПД, вес, стоимость активных материалов, номинальный ток элементов преобразователя частоты. Методика. Расчет характеристик электрической машины с помощью рещения двухмерных краевых магнитостатических задач. Результаты. Произведено сопоставление двух типов однофазных машин с магнитами на статоре; получено расчетное сравнение характеристик однофазной электрической машины с переменным направлением потока и однофазной гибридной вентильно-индукторной реактивной машины; получены результаты сравнения массы и размеров КПД двух машин. Научная новизна. Впервые получены результаты сравнения однофазной электрической машины с переменным направлением потока и однофазной гибридной вентильно-индукторной реактивной машины. Практическое значение. Полученные результаты могут помочь при выборе лучшей конструкцией электродвигателя в рассматриваемых приложениях: электрический турбонаддуб, бытовые приборы, вентиляторы, насосы и компрессоры малой мощности и т.д. Библ. 15, табл. 2 , рис. 13.

Ключевые слова: высокоскоростные машины, гибридная вентильно-индукторная реактивная машина, машина с переменным направлением магнитного потока, машина с постоянными магнитами, однофазные электрические машины, специальные электрические машины.

Introduction. Single-phase synchronous machines with magnets on the rotor [1] and brushless machines with permanent magnets on the stator [2-9] are used in high-speed low power applications where speed control and low cost are required.

The main advantage of machines with magnets on the rotor compared to a synchronous machine with magnets on the rotor is a simple toothed rotor, which is a laminated steel package mounted on a shaft. This improves reliability, simplifies rotor manufacturing technology, and reduces rotor cost in high-speed applications.

In $[2,3]$, a single-phase hybrid switched reluctance machine (HSRM) is described (Fig. 1). Adding permanent magnets to the stator solves the problem of initial

(c) V.A. Prakht, V.A. Dmitrievskii, V.M. Kazakbaev, S.Kh. Oshurbekov 
positioning of the rotor. Therefore, starting the motor is possible, even in a single-phase version. In addition, the presence of magnets on the stator reduces the mass of HSRM, compared with HSRM without magnets. The size and diameter of the HSRM rotor are reduced, which is especially important for high-speed applications. Compared to a single-phase synchronous machine with magnets on the rotor, HSRM has the following advantages:

1) structurally simple and reliable gear rotor;

2) cheap ferrites can be used in the HSRM design, and expensive rare-earth magnets should be used in a traditional synchronous machine;

3) fewer transistors in the inverter.

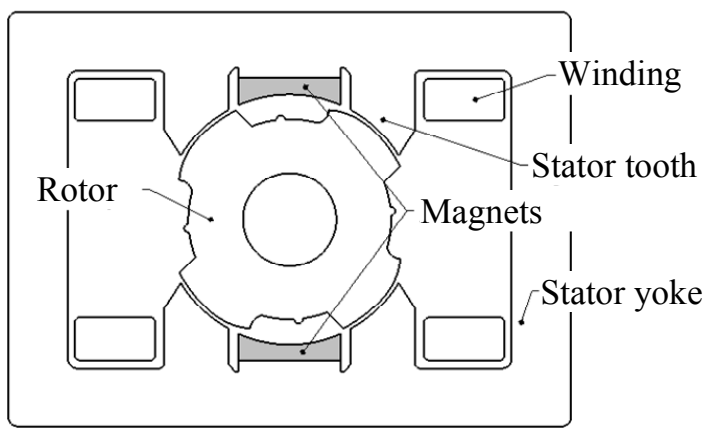

Fig. 1. A single-phase hybrid switched reluctance machine [2]

Despite the advantages of HSRM noted above, this machine has the following disadvantage compared to a single-phase synchronous machine with magnets on the rotor: HSRM is powered by unipolar DC pulses. A synchronous machine with magnets on the rotor is an AC machine. Therefore, in order to achieve a current with the same amplitude (half-span) in the case of HSRM, it is required that the current has a significantly higher modulus value. Thus, the effective and maximum currents in the HSRM phase are much larger than that of a similar single-phase synchronous machine with magnets on the rotor. In this regard, the cost and dimensions of the frequency converter for HSRM increase, as well as the losses in the frequency converter increase.

A good alternative to HSRM and a traditional single-phase synchronous machine with magnets on the rotor can be a flux reversal machine (FRM). A singlephase FRM with three teeth on the rotor and four magnetic poles on the stator (Fig. 2) was first described in [4].

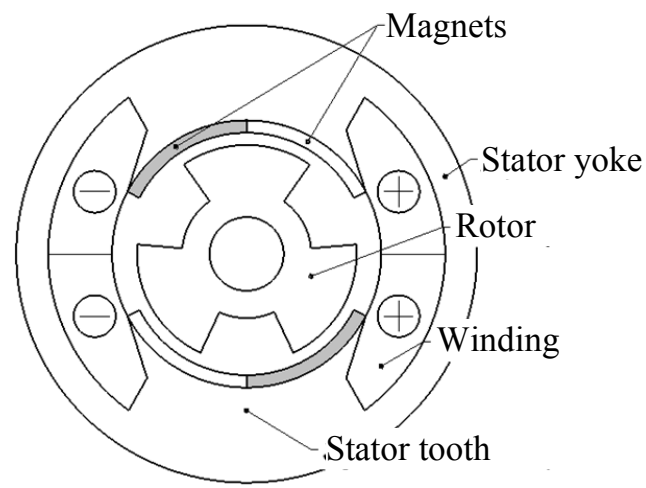

Fig. 2. FRM design according to [4]
A single-phase FRM has a simple and toothed rotor, like HSRM. The placement of permanent magnets on the FRM stator provides simplicity of design and reliability, as well as low weight and dimensions. At the same time, FRM is an AC machine, like a synchronous machine with magnets on the rotor. Current pulses of different polarity in FRM can occupy a significant part of the period. Therefore, the effective and maximum currents in the FRM phase are less than for HSRM. This makes it possible to use a frequency converter for FRM, in which the main power elements have lowers value of the effective and maximum currents. Also, in the frequency converter for FRM, there are less energy losses than for HSRM, and, therefore, the dimensions of the radiator and the overall dimensions are smaller.

However, the FRM design described in [4] has the following disadvantages: 1) a decrease in specific power and efficiency, since a third of the inner surface of the stator is not used; 2) the lack of symmetry of the machine at a rotation interval of $180^{\circ}$ causes uncompensated radial forces acting on the rotor; 3 ) these uncompensated radial forces reduce the service life of the bearings. To overcome the above disadvantages of FRM described in [4], in the patent [5] and papers [6, 7], a single-phase FRM presented in Fig. 3 is proposed.

In FRM (Fig. 3) the entire stator surface is used due to the use of half-closed slots. The HSRM has open stator slots, which reduces the specific torque and efficiency in comparison with FRM.

Despite the drawbacks of HSRM noted above, compared with FRM, cheap ferrite magnets can be used in the design of HSRM [3], while only rare-earth magnets can be used for FRM. This advantage of HSRM can be especially important when designing low-cost drives for household appliances, electrical tools, the automotive industry, blowers, etc.

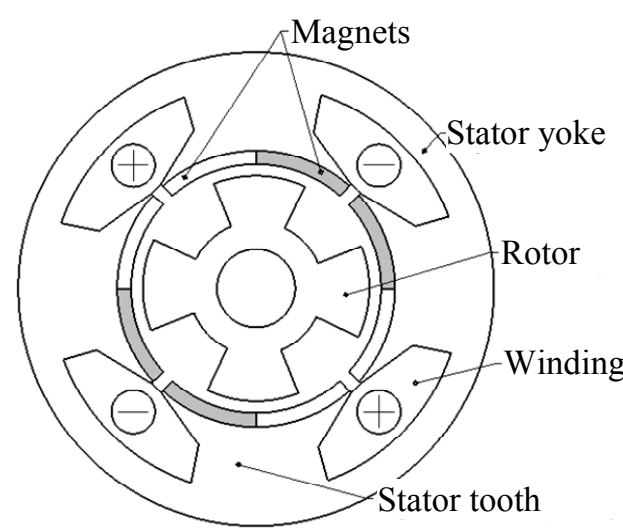

Fig. 3. FRM design according to $[5,6]$

Comparison of different types of electric machines by weight and cost of active materials, efficiency is of great importance when choosing the type of drive for various applications, as shown in the example of threephase machines [10-12]. As a review of the literature shows, a comparison of high-speed FRM and HSRM is not described in the literature, therefore, such a comparison is relevant and new when choosing the type of drive for single-phase high-speed applications. 
The goal of the work is study of the characteristics of two types of single-phase high-speed electric machines with magnets on the stator - FRM and HSRM. Both machines are designed for low-power drives of household appliances (rated mechanical power $754 \mathrm{~W}$, rated speed $18000 \mathrm{rpm}$, rated torque $0.4 \mathrm{~N} \cdot \mathrm{m}$ ). The main characteristics and data for the HSRM are taken from [2]. The FRM was designed based on the technique described in [8]. For both machines, a comparison is made according to the efficiency and the mass of active materials. The advantages and disadvantages of singlephase FRM and HSRM are analyzed.

Modelling and calculation of FRM characteristics. The modelling and calculation of the characteristics of the FRM was performed using the Finite Element Method based on the technique described in [9]. The technique is based on the solution of magnetostatic boundary value problems, with different positions of the rotor corresponding to different times. All these boundary value problems have the same computational domain, divided into two subdomains in the middle of the air gap. The rotation is taken into account by the boundary condition stitching these subdomains in accordance with the rotation of the rotor [6]. The diameter of the FRM stator package was chosen significantly less than that of the HSRM and equal to $51 \mathrm{~mm}$. The length of the package was chosen equal to $30 \mathrm{~mm}$, as in HSRM. Rare-earth magnets with magnetic flux density of $1.2 \mathrm{~T}$ were selected for FRM. The frequency of supply of the fundamental harmonic of the FRM current is equal to $1200 \mathrm{~Hz}$, as for HSRM.

Figure 4 shows the distribution of the magnetic flux density module for FRM. The rotor tooth is located above the middle of the stator slot.

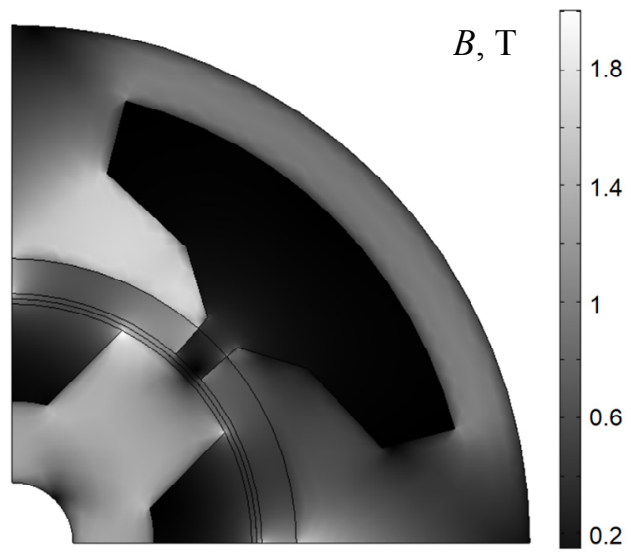

Fig. 4. Magnetic flux density module for FRM at torque of $0.4 \mathrm{~N} \cdot \mathrm{m}$

In Fig. 5,a, the calculated losses in copper $P_{c u}$, magnetic cores of the stator $P_{s t}$ and rotor $P_{r t}$, as well as in magnets $P_{\text {magn }}$ are shown for FRM for the rated speed $(18000 \mathrm{rpm})$ at different values of the load torque:

1) mechanical power $188.5 \mathrm{~W}$, torque $0.1 \mathrm{~N} \cdot \mathrm{m}$;

2) mechanical power $377 \mathrm{~W}$, torque $0.2 \mathrm{~N} \cdot \mathrm{m}$;

3) mechanical power $565 \mathrm{~W}$, torque $0.3 \mathrm{~N} \cdot \mathrm{m}$;

4) mechanical power $754 \mathrm{~W}$, torque $0.4 \mathrm{~N} \cdot \mathrm{m}$ (nominal mode).

Other losses (in bearings and ventilation) were assumed to be $15 \mathrm{~W}$ at rated speed. The largest losses of FRM in all modes are concentrated in the winding.
Figure $5, b$ shows the instantaneous values of FRM currents for different values of the torque. The moments of the beginning and end of a positive voltage pulse are indicated by «on $+»$ and «off $+»$, respectively. The moments of the beginning and end of a negative voltage pulse are indicated by «on-») and «off-», respectively. The graphs show that the current is piecewise smooth with kinks at the moments of switching.
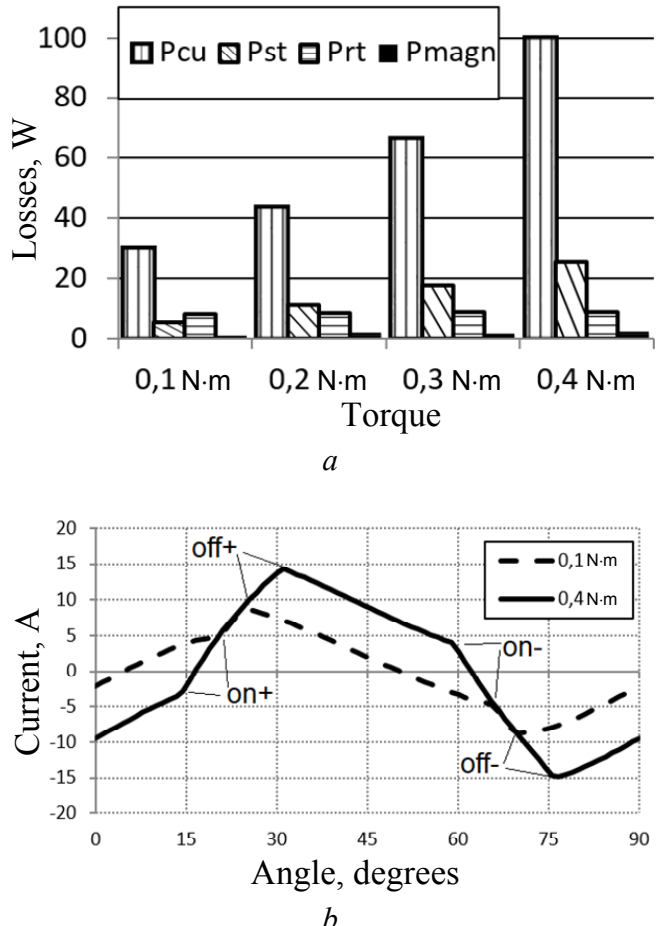

Fig. 5. Losses of FRM at the rated speed at various load torques (a) and the dependence of the current on the position of the rotor $(b)$

Figure 6, $a$ shows the dependence of the fill factor of the supply voltage pulses (the fraction of the electric period occupied by voltage pulses of one or another polarity) on the average value of the FRM torque. With an increase in the required torque value, the fill factor increases linearly. The dependence of the effective current value on the average torque of the FRM is shown in Fig. 6, $b$. The effective value of the current increases nonlinearly with increasing torque. The remaining characteristics for FRM are presented in the next section, in comparison with HSRM.

Comparison of the characteristics of FRM and HSRM. Tables 1, 2 show the main characteristics of single-phase FRM and HSRM (rated mechanical power $754 \mathrm{~W}$, rated speed $18000 \mathrm{rpm}$ ).

The price per $1 \mathrm{~kg}$ of permanent magnets depends not only on the material, but also on the size of the blocks used $[13,14]$. The price of NeFeB-magnets of the required size for FRM is $137.78 \mathrm{USD} / \mathrm{kg}$ [13]. The price of ferrite magnets of the required size for HSRM is 67.20 $\mathrm{USD} / \mathrm{kg}[14]$.

As can be seen from Table 2, the cost of active materials for HSRM is 1.9 times less than for FRM. However, FRM is 1.8 times less in mass than HSRM. Therefore, in devices that the user holds in his/her hands (for example, in an angle grinder, in a circular saw, in a 


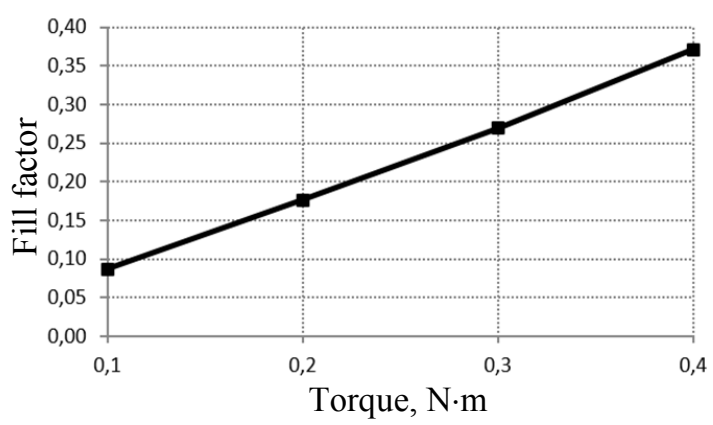

$a$

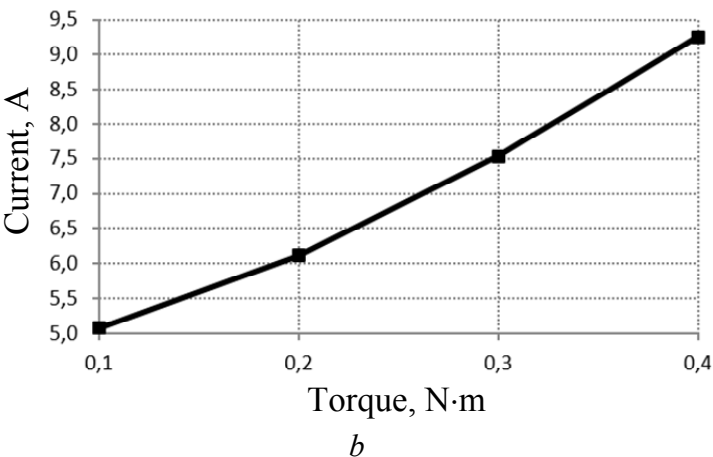

Fig. 6. Dependence of the fill factor $(a)$ and the effective current value $(b)$ on the torque of FRM

cordless power tool, in a garden blower, in a handheld vacuum cleaner), as well as in other applications where it is important to reduce the dimensions, it is advisable to use FRM. In applications where weight reduction is not so important, but it is important to reduce the cost of the machine, for example, in hand dryers, in a blender, in a miter saw, it is advisable to use HSRM.

Table 1

Rated parameters of electrical machines

\begin{tabular}{|l|c|c|}
\hline \multicolumn{1}{|c|}{ Parameter } & FRM & HSRM [2] \\
\hline Load torque, $\mathrm{N} \cdot \mathrm{m}$ & 0.4 & 0.4 \\
\hline $\begin{array}{l}\text { Fundamental harmonic } \\
\text { frequency, } \mathrm{Hz}\end{array}$ & 1200 & 1200 \\
\hline DC link voltage, $\mathrm{V}$ & 320 & 320 \\
\hline $\begin{array}{l}\text { Effective value of current in } \\
\text { phase, } \mathrm{A}\end{array}$ & 9.25 & 17.8 \\
\hline $\begin{array}{l}\text { Maximum value of current } \\
\text { in phase, A }\end{array}$ & 14.8 & 34.8 \\
\hline Efficiency, \% & 83 & 72 \\
\hline
\end{tabular}

The size of the FRM rotor is significantly smaller than that of the HSRM: 1) the diameter of the rotor is 1.4 times smaller; 2) the mass of the rotor is 2.3 times less; 3 ) the moment of inertia of the rotor is 5 times less. This advantage of FRM is especially important for all highspeed applications, since it allows to significantly reduce the centrifugal forces acting on the rotor, as well as reduce the load on the rotor bearing assembly and extend the service life. Also, the small moment of inertia of the rotor is very important in applications such as electric turbocharging [15], since it allows increasing the reaction speed to the reference signal and significantly improving the dynamic characteristics of turbocharging systems of gasoline and diesel internal combustion engines.
Table 2

Cost of active materials, weight and size of electrical machines

\begin{tabular}{|l|c|c|}
\hline \multicolumn{1}{|c|}{ Parameter } & FRM & HSRM [2] \\
\hline $\begin{array}{l}\text { External dimension of } \\
\text { stator magnetic } \\
\text { circuit, mm }\end{array}$ & $\varnothing 51$ & $78 \times 58$ \\
\hline $\begin{array}{l}\text { Active part length, } \\
\text { mm }\end{array}$ & 30 & 30 \\
\hline Air gap, mm & 0.5 & $0.5-1.2$ \\
\hline $\begin{array}{l}\text { Rotor outer diameter, } \\
\text { mm }\end{array}$ & 23.6 & $\approx 34$ \\
\hline $\begin{array}{l}\text { Rotor moment of } \\
\text { inertia, kg·cm }\end{array}$ & 0.041 & 0.205 \\
\hline $\begin{array}{l}\text { Permanent magnet } \\
\text { type }\end{array}$ & Rare-earth & Ferrite* \\
\hline $\begin{array}{l}\text { Permanent magnet } \\
\text { thickness, mm }\end{array}$ & 1.7 & 17 \\
\hline $\begin{array}{l}\text { Mass of permanent } \\
\text { magnets, g }\end{array}$ & 28 & 494 \\
\hline Mass of stator steel, g & 214 & 138 \\
\hline Mass of rotor steel, g & 61 & 99 \\
\hline Mass of copper, g & 100 & 731 \\
\hline $\begin{array}{l}\text { Total mass of active } \\
\text { materials, g }\end{array}$ & 403 & $\begin{array}{l}\text { Cost of active } \\
\text { materials, USD }\end{array}$ \\
\hline
\end{tabular}

* Note to Table 2: in the paper [5] there is no data on the type of magnets in the HSRM, however, in [3] it is noted that ferrite magnets are used for the HSRM. When calculating the cost of active materials, the following prices were taken: $1 \mathrm{USD} / \mathrm{kg}$ for steel, $7 \mathrm{USD} / \mathrm{kg}$ for copper [10].

Figure 7 presents the values of the efficiency of FRM and HSRM for rotation speed of $18000 \mathrm{rpm}$. The FRM has a higher value of efficiency, which means less losses, less heating of the winding and a longer mode of operation during overloads in torque and power.

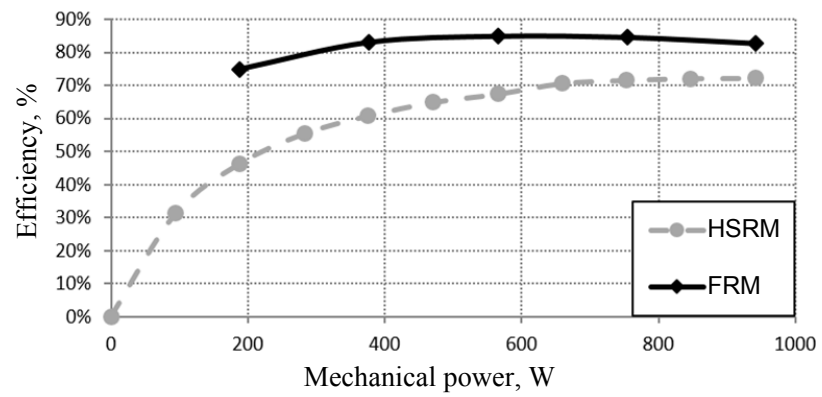

Fig. 7. Comparison of the FRM and HSRM efficiency

Figure 8 shows the torque values of the FRM and HSRM depending on the angle of rotation of the machine. The torque of FRM has a region of negative values and a higher value of torque pulsations, in comparison with HSRM. However, the pulsations of the FRM torque can be significantly reduced as a result of optimizing the geometry of the machine and can be comparable with HSRM. 


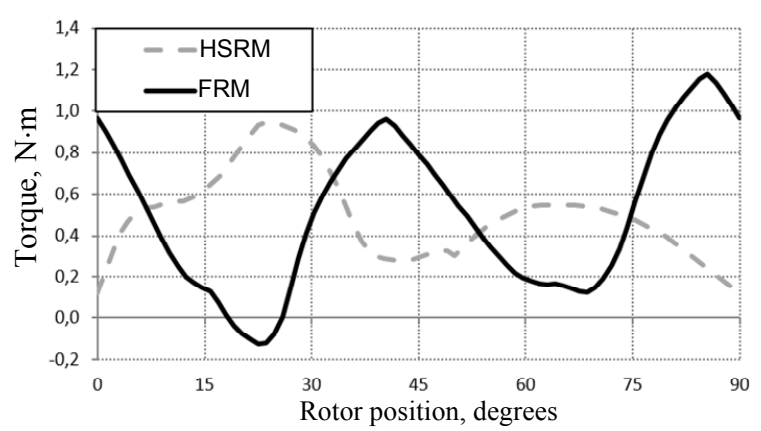

Fig. 8. Comparison of the graphs of the torque of the considered machines

Figures 9-11 show instantaneous values of voltage, currents, and power of FRM and HSRM for torque of $0.4 \mathrm{~N} \cdot \mathrm{m}$ and rotation speed of $18000 \mathrm{rpm}$.

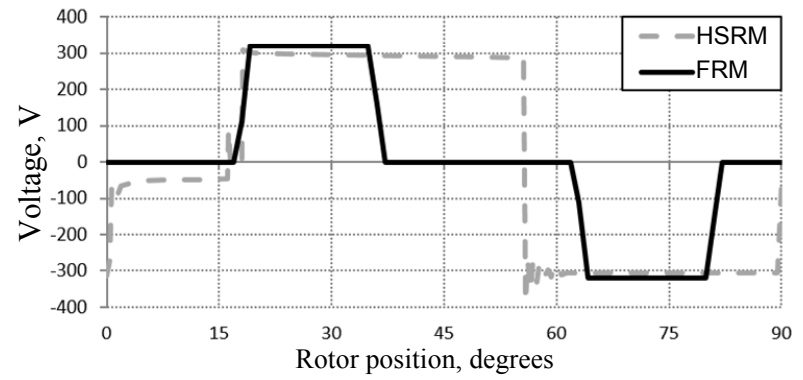

Fig. 9. Comparison of machine voltage graphs at torque of $0.4 \mathrm{~N} \cdot \mathrm{m}$

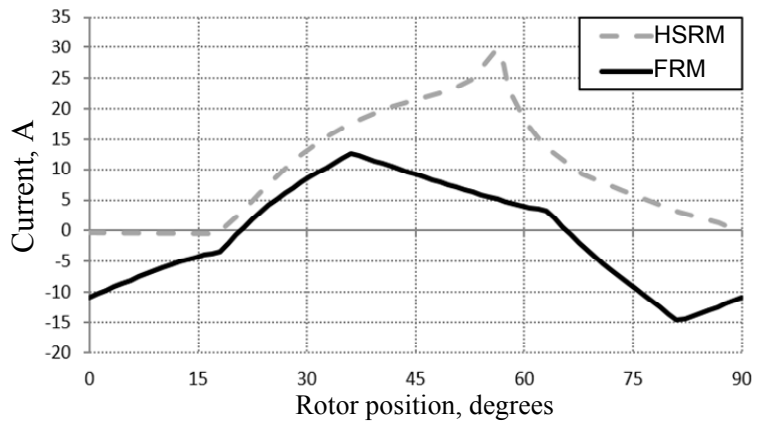

Fig. 10. Comparison of machine current graphs at torque of $0.4 \mathrm{~N} \cdot \mathrm{m}$

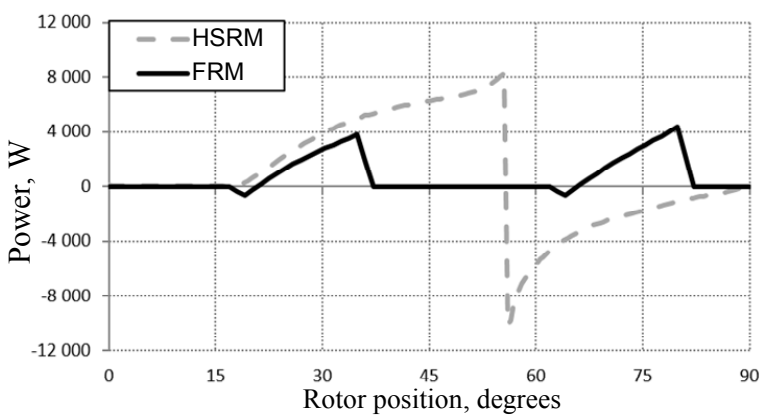

Fig. 11. Comparison of machine electrical power at torque of $0.4 \mathrm{~N} \cdot \mathrm{m}$

As can be seen from Fig. 9-11, the maximum current value in the FRM phase is $14.8 \mathrm{~A}$, and for HSRM - 34.8 A. The effective current value in the FRM phase is $9.25 \mathrm{~A}$, and for HSRM - $17.8 \mathrm{~A}$. The maximum value of instantaneous power consumption of the FRM from the frequency converter is $4.4 \mathrm{~kW}$, and for HSRM $-9.8 \mathrm{~kW}$.
The average value of the instantaneous power consumption of the FRM from the frequency converter is $908 \mathrm{~W}$, and for HSRM - $1047 \mathrm{~W}$. The frequency converter for the HSRM (Fig. 12) has a smaller number of transistors than for FRM (Fig. 13).

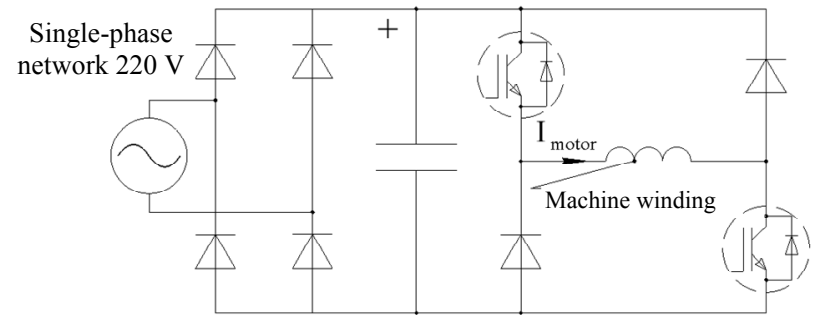

Fig. 12. Frequency converters for HSRM

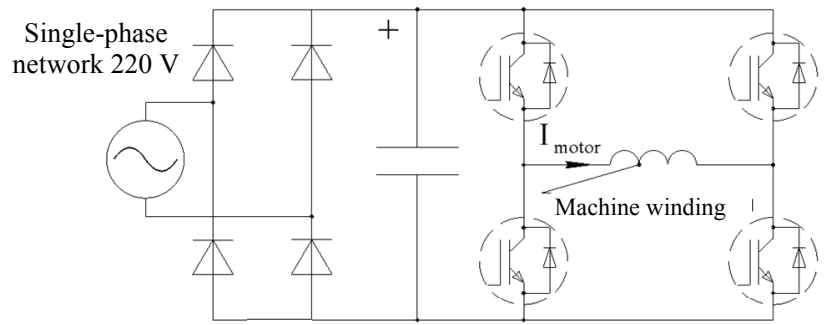

Fig. 13. Frequency converters for FRM

However, FRM requires power elements with a lower maximum current value and a smaller cooling radiator. Also, for HSRM, a capacitor of a larger capacity in the DC link is required, since the maximum value of the instantaneous power consumed by the inverter from the DC link is several times larger than for FRM. Therefore, it is of interest to compare the power losses, cost, mass, and size of frequency converters for FRM and HSRM. The design and comparison of frequency converters for FRM and HSRM will be performed in the further works.

\section{Conclusions.}

1. The paper compares two types of single-phase machines with magnets on the stator. The FRM has a significantly higher value of efficiency than HSRM, and, consequently, less heating of the winding.

2. The cost of active materials for the HSRM is 1.9 times less than for FRM. However, the FRM is 1.8 times less in mass than HSRM. Therefore, in devices that are held in hands, for example, in an electric tool, as well as in other applications where it is important to reduce the size, it is advisable to use FRM. In applications where weight reduction is not so important, but it is important to reduce the cost of the machine, it is advisable to use HSRM.

The effective current value in the FRM phase is 9.25 A, while the effective current value in the HSRM phase is 17.8 A. Therefore, the FRM needs power elements with a lower maximum current value and a smaller cooling radiator. The HSRM also requires a larger radiator and a larger capacitor in the DC link. Despite the simpler circuit of the frequency converter for HSRM, its mass will be greater than for FRM.

\section{Acknowledgment.}

The research was conducted as part of theme no. 8.9549.2017/8.9. within the frame of the government task 
of the Ministry of Education and Science of the Russian Federation regarding R\&D.

\section{REFERENCES}

1. Bentouati S., Zhu Z., Howe D. Permanent magnet brushless DC motors for consumer products. Proceedings of the 9th International Conference on Electrical Machines and Drives (Conf. Publ. No. 468), pp. 118-122, Canterbury, UK, 1-3 September 1999.

2. Jeong K., Ahn J. Design and characteristics analysis of a novel single-phase hybrid SRM for blender application. Journal of Electrical Engineering and Technology, 2018, vol. 13, no. 5, pp. 1996-2003. doi: 10.5370/JEET.2018.13.5.1996.

3. Torok V., Loreth K. The world's simplest motor for variable speed control? The Cyrano motor, a PM-biased SR-motor of high torque density. Proceedings of the 1993 5th European Conference on Power Electronics and Applications, Brighton, UK, 13-16 Sept. 1993.

4. Deodhar R.P., Andersson S., Boldea I., Miller T.J.E. The flux-reversal machine: a new brushless doubly-salient permanent-magnet machine. IEEE Transactions on Industry Applications, 1997, vol. 33, no. 4, pp. 925-934. doi: 10.1109/28.605734.

5. Dmitrievskii V.A., Prakht V.A. Odnofaznaia elektricheskaia mashina [Single-phase electrical machine]. Patent Russian Federation, no. 2524144, 2014. (Rus).

6. Dmitrievskii V., Prakht V., Pozdeev A., Klimarev V., Mikhalitsyn A. Angular grinder with new flux reversal motor. Proceedings of the 18th International Conference on Electrical Machines and Systems (ICEMS), pp. 1366-1371, Pattaya, Thailand, 25-28 October 2015.

7. Dmitrievskii V.A., Prakht V.A. Mathematical simulation of a high-speed single-phase machine with alternating current direction. Russian Electrical Engineering, 2016, vol. 87, no. 6, pp. 327-332. doi: 10.3103/s1068371216060043.

8. Dmitrievskii V., Prakht V., Kazakbaev V., Sarapulov S. Steady-state model of a single-phase flux reversal motor. Proceedings of 58th International Scientific Conference on Power and Electrical Engineering of Riga Technical University (RTUCON 2017), pp. 1-5, Riga, Latvia, 12-13 October 2017.

9. Dmitrievskii V., Prakht V., Kazakbaev V., Sarapulov S. Optimal design of a high-speed single-phase flux reversal motor for vacuum cleaners. Energies, 2018, vol. 11, no. 12, p. 3334. doi: $10.3390 /$ en11123334.
10. Goss J., Popescu M., Staton D. A comparison of an interior permanent magnet and copper rotor induction motor in a hybrid electric vehicle application. Electric Machines \& Drives Conference (IEMDC), 2013 IEEE International, pp. 220-225, Chicago, IL, USA, 12-15 May 2013. doi: 10.1109/iemdc.2013.6556256.

11. Rahman T., Mohammadi M.H., Humphries K., Lowther D.A. Comparison of fractional-slot concentrated winding and PM-assisted synchronous reluctance motors for class IV electric vehicles. Proceedings of IEEE Int. Electrical Machines and Drives Conf. (IEMDC 2017), Miami, pp. 1-7, USA, May 2017. doi: 10.1109/iemdc.2017.8002173.

12. Calvo E., Potoradi D. Synchronous reluctance motors with and without permanent magnets for high performance low cost electrical drives. Proceedings of 5th International Electric Drives Production Conference (EDPC 2015), pp. 1-7, Nuremberg, Germany, 15-16 September 2015. doi: 10.1109/edpc.2015.7323220.

13. Chen Yang NdFeB Magnets. Price List of Standard Block Magnets. Available at: http://www.ndfebmagnets.de/CYPriceList-NdFeB-Block.pdf (accessed 05 July 2019).

14. IBSMagnet. Hard ferrite magnets. Available at: https://ibsmagnet.com/products/dauermagnete/hartferrit.php (accessed 05 July 2019).

15. Lee W., Kim J.H., Choi W., Sarlioglu B. Torque Ripple Minimization Control Technique of High-Speed Single-Phase Brushless DC Motor for Electric Turbocharger. IEEE Transactions on Vehicular Technology, 2018, vol. 67, no. 11, pp. 10357-10365. doi: 10.1109/tvt.2018.2866779.

Received 24.09.2019

V.A. Prakht ${ }^{1}$, Candidate of Technical Science,

V.A. Dmitrievskii ${ }^{1}$, Candidate of Technical Science,

V.M. Kazakbaev ${ }^{1}$, Candidate of Technical Science,

S.Kh. Oshurbekov ${ }^{1}$,

${ }^{1}$ Ural Federal University,

19, Mira Str., Ekaterinburg, 620002, Russia,

e-mail: va.prakht@urfu.ru, vladimir.dmitrievsky@urfu.ru, vadim.kazakbaev@urfu.ru, s.oshurbekov@mail.ru

How to cite this article:

Prakht V.A., Dmitrievskii V.A., Kazakbaev V.M., Oshurbekov S.Kh. Comparative analysis of two high-speed singlephase electrical machines with permanent magnets on the stator. Electrical engineering \& electromechanics, 2020, no.2, pp. 20-25. doi: 10.20998/2074-272X.2020.2.03. 